\title{
Antibacterial Activities of Nano Magnetite ZnO Produced in Aerobic and Anaerobic Condition by Pseudomonas stutzeri
}

\author{
Mansoureh Mirhendi ${ }^{1}$, Giti Emtiazi ${ }^{1, *}$, Rasoul Roghanian ${ }^{1}$ \\ ${ }^{1}$ Department of Biology, University of Isfahan, Isfahan, IR Iran \\ *Corresponding author: Giti Emtiazi, Department of Biology, University of Isfahan, Isfahan, IR Iran. Tel: +98-3117932457, Fax: +98-3117932456. Email:, E-mail: Emtiazi@yahoo.com.
}

Received: January 13, 2013; Revised: January 23, 2013; Accepted: January 27, 2013

\begin{abstract}
Background: Zincite $(\mathrm{ZnO})$ nanoparticles are usually prepared by decomposition of zinc acetate, hot injection and heating-up method. Microbial nanoparticle production has been developed recently, since they are clean, nontoxic and cheap. Bacteria are known as environmentally friendly nanoparticle factories using cheap, renewable carbon sources. Nanometer-sized nanoparticles are talented for different applications. For example, semiconductor nanoparticles such as Sphalerite $(\mathrm{ZnS})$ are used as fluorescence probes for labeling of biological tissues. These days, magnetic nanoparticles are applied routinely in magnetic resonance imaging (MRI) as contrastenhancement agents. Also, nano $\mathrm{ZnO}$ is useful in petrochemical industries.

Objectives: The aim of this study was to produce nanoparticles such as $\mathrm{ZnO}, \mathrm{ZnS}$, and $\mathrm{Zn}$ by using biofilm of a resistant bacterium (i.e. Pseudomonas stutzeri) on a piece of pure zinc.

Materials and Methods: P. stutzeri strain CS-2 was isolated from enriched soil containing methyl tertiary butyl ether (MTBE). Since the bacterium has many metal resistance genes, it was a good candidate for producing nanoparticles. A piece of pure zinc metal, sized 3.1cm was put on a solid medium (nutrient agar). The biofilm was isolated and analyzed by X-Ray diffractometer (XRD). The optimum environmental condition for producing nanoparticles was investigated. Moreover, antibacterial activity as well as magnetic property of the produced nanoparticles was studied. Finally, PCR reaction for specific PST gene was done.

Results: Analysis by XRD showed 78.1\% ZnO (sized $24 \mathrm{~nm}$ ), 2.5\% Zn (sized $44.88 \mathrm{~nm}$ ) and $4.8 \% \mathrm{ZnS}$ (sized $12 \mathrm{~nm}$ ) produced by P. stutzeri. The nanoparticles showed anti-bacterial activity against some of the Gram positive and negative bacteria. In addition, the nanoparticles showed magnetic properties. The best condition for nano zinc production was at $\mathrm{pH} 7$, in the light and at $37^{\circ} \mathrm{C}$. CzcC gene with $399 \mathrm{~Kb}$ was detected from the isolated $P$. stutzeri.

Conclusions: Although previous studies have shown that P. stutzeri is able to produce silver nanoparticles in silver salt solution, but in this study, for the first time $\mathrm{ZnO}, \mathrm{ZnS}$, and $\mathrm{Zn}$ nanoparticles were detected on a biofilm of zinc metal. Isolation of these nanoparticles by this method is very cost effective, non-toxic, clean and compatible to Eco (green chemistry).
\end{abstract}

Keywords: Pseudomonas stutzeri; Magnetite nanoparticle

\section{Background}

Nano (according to Merriam-Webster Dictionary) meansone-billionth part of a substance. The high surface area to volume ratio of nanoparticles makes nanoparticles very reactive or catalytic (1). Synthesis of nanoparticles by physical methods usually requires high operating temperatures or pressures, such as production of $\mathrm{ZnO}$ (zinc oxide) nano-particles by injection of heat and hydrothermal method or synthesis of $\mathrm{ZnS}$ (zinc sulphide) by ultrasonic $(2,3)$. Chemical methods for synthesis of zinc nano-particles similar to zinc acetate solution, spray pyrolysis method by using a solution of zinc acetate and pressure, or production of $\mathrm{Zn}$ and $\mathrm{ZnO}$ nanoparticles by chemical vapor deposition with laser create problems and contamination $(4,5)$. It is necessary to develop, clean, nontoxic synthesis methods compatible with Eco
(Green Chemistry). Recent developments have used microorganisms for the synthesis of nanoparticles (6-10). Undoubtedly, nanoparticles have an important role in the future technology. Zinc, zinc oxide and zinc sulfide nanoparticles are used for various biomedical reasons due to their biological characteristics. For instance, $\mathrm{ZnS}$ nanoparticles are used as fluorescent probes and for optical imaging labeling of biological tissues. Routinely, magnetic nanoparticles are used as factors for increasing MRI contrast. Designing and modifying the surface of $\mathrm{ZnO}$ nanoparticles are used for destruction of tumor cells. Drug delivery is another application of zinc oxide nanoparticles (11-14).

Nano zinc oxide is useful in oil, gas and petrochemical industries as a catalyst. It is also applied for producing rubber, glazing, electronics, cosmetic, and in absorption

Implication for health policy/practice/research/medical education:

In this study production of nanoparticles such as $\mathrm{ZnO}, \mathrm{ZnS}$, and $\mathrm{Zn}$, using biofilm of a resistant bacterium (i.e. Pseudomonas stutzeri) on a piece of pure zinc was done as a very cost effective, non-toxic, clean and compatible to Eco (green chemistry) method.

Copyright (C) 2013, Ahvaz JundishapurUniversity of Medical Sciences; Published by Kowsar Corp. This is an open-access article distributed under the terms of the Creative Commons Attribution License, which permits unrestricted use, distribution, and reproduction in any medium, provided the original work is properly cited. 
towers, as well as acting as a catalyst for conventional petrochemical industries and for absorbing ammonia gas. Zinc oxide is used as a highly selective sensor for ammonia gas detection. Also it is useful for $\mathrm{H}_{2} \mathrm{~S}$ removal from drilling fluid $(15,16)$. Zinc oxide nanoparticles are used for production of antimicrobial fabrics (17).

Microorganisms are used as factories for producing 1-200 $\mathrm{nm}$ nanoparticles at room temperature or higher temperatures (in thermophiles) using cheap, renewable carbon sources such as fiber or starch. Microbial resistance against heavy metal ions has been exploited for biological metal recovery via reduction of metal ions or formation of metal sulfides. Most metal ions are toxic for bacteria so reducing ions and forming water from soluble complexes,results a defense mechanism to overcome such toxicity in bacteria $(18,19)$. Most microorganisms produce their nano-materials by bio-mineralization. Pseudomonas stutzeri is a Gram-negative, rod-shaped, motile, single polar-flagellated, soil bacterium first isolated from human spinal fluid. The production of silver nanoparticles and zinc sulphate with a range of 10-20 nm have been reported for P. stutzeri and Streptomyce ssp. HBUM171191 (20, 21).

P. stutzeri contains the CzcC gene. The PSTAB_1242 cobalt-zinc-cadmium resistance protein ( $\mathrm{CzcC}$ ) gene sequence from $P$. stutzeri was obtained from the National Center for Biotechnology Information (NCBI). This gene is a metal resistance gene that transports Zinc ions across the cytoplasmic membrane and thus may be involved in producing nano zinc.

\section{Objectives}

The aim of this study was to produce nanoparticles such as $\mathrm{ZnO}, \mathrm{ZnS}$, and $\mathrm{Zn}$ by using biofilm of a resistant bacterium (i.e. P. stutzeri) on a piece of pure zinc. Optimization of environmental conditions for production of nanoparticles, their biocide effects as well as magnetic properties were other goals of this investigation. Finally, a PCR reaction for the specific PST gene was done. To the best of our knowledge, there are no reports for nano zinc production by bacteria.

\section{Materials and Methods}

Previously, P. stutzeri strain CS-2 had been isolated from methyl tertiary butyl ether (MTBE) enriched soil and identified by PCR of 16srRNA with two forward and reverses universal primers. This isolate was submitted to NCBI with accession number of FM 957535.1 GI: 220980578.

\subsection{Nano Zn Production by P. stutzeri}

P. stutzeri was cultured in nutrient agar and incubated for 2 days at $27^{\circ} \mathrm{C}$. Then, one piece of sterile $\mathrm{Zn}$ metal sized
$3.1 \mathrm{~cm}$ was put on the culture and incubated for 2 weeks at $27{ }^{\circ} \mathrm{C}$. Yellowish-white bio-film produced on the piece of zinc metal was separated and dried at $37{ }^{\circ} \mathrm{C}$. The dried biofilm was sent to the Central Lab of Isfahan University and studied by X-Ray diffractometer (XRD, Instrument Specifications: Bruker, D8ADVANCE, Germany, X-Ray Tube Anode: $\mathrm{Cu}$, Wavelength: $1.5406 \AA$ ( $\mathrm{Cu} \mathrm{K \alpha}$ ), Filter: Ni). The percentage and size of the nanoparticles were determined by XRD. Also, P. stutzeri was cultured in two flasks of nutrient broth containing a piece of sterile zinc metal sized $3.1 \mathrm{~cm}$. One flask was incubatedat aerobic and the other at anaerobic conditions for 2 weeks at $27^{\circ} \mathrm{C} ; \mathrm{pH}=7$ for the aerobic condition and, $\mathrm{KOH}$ was added to obtain $\mathrm{pH}=12$ for the anaerobic condition that was filled with paraffin. After incubation, the nutrient broth medium treated at the aerobic condition was centrifuged at 13000 rpm for 10 minutes. The supernatant and sedimentation of cells were dried at $37^{\circ} \mathrm{C}$ and the samples were analyzed by XRD. Also the dried biofilm produced from the anaerobic situation was analyzed by XRD.

\subsection{Production of Nano ZnS}

P. stutzeri was cultured in a nutrient broth and nutrient agar containing $\mathrm{Na}_{2} \mathrm{~S} 0.04 \mathrm{M}$ in aerobic and anaerobic condition at $27^{\circ} \mathrm{C}$. The sterile zinc metal piece was put in the above mentioned media and the effect of $\mathrm{Na}_{2} \mathrm{~S}$ in production of ZnS was investigated by XRD.

\subsection{The Effect of Environmental Condition on Nano ZnO Production}

The P. stutzeri was grown on nutrient broth and the effects of various $\mathrm{pH}$ (4, 7 and 11.5), light (on and off), and temperatures $\left(23^{\circ} \mathrm{C}\right.$ and $37^{\circ} \mathrm{C}$ ) were studied to determine the optimal condition required for the production of nano $\mathrm{ZnO}$.

\subsection{The Antibacterial Activity of $\mathrm{ZnO}$}

The antibacterial activity of ZnO produced by P. stutzeri was assayed on nutrient agar against Escherichia coli, Staphylococcus aureus, Brevundimonas diminuta and P.stutzeri by disc diffusion in lawn culture of microorganisms by the Kirby-Bauer disk diffusion method (22).

\subsection{PCR Reaction of PST Gene}

Two primers, Forward 5'CGAGCGGGCTGCTAAGGTCG3' and Reverse 5'ACGAGGTTGACGCGCTCACG3' were designated for the PSTAB-1242 cobalt-zinc-cadmium resistance protein $\mathrm{CzcC}$ gene and $\mathrm{PCR}$ reaction was performed at the following condition: denaturing at $94{ }^{\circ} \mathrm{C}$ for 45 seconds, annealing at $55{ }^{\circ} \mathrm{C}$ for 60 seconds and extension at $72{ }^{\circ} \mathrm{C}$ for 90 seconds. 


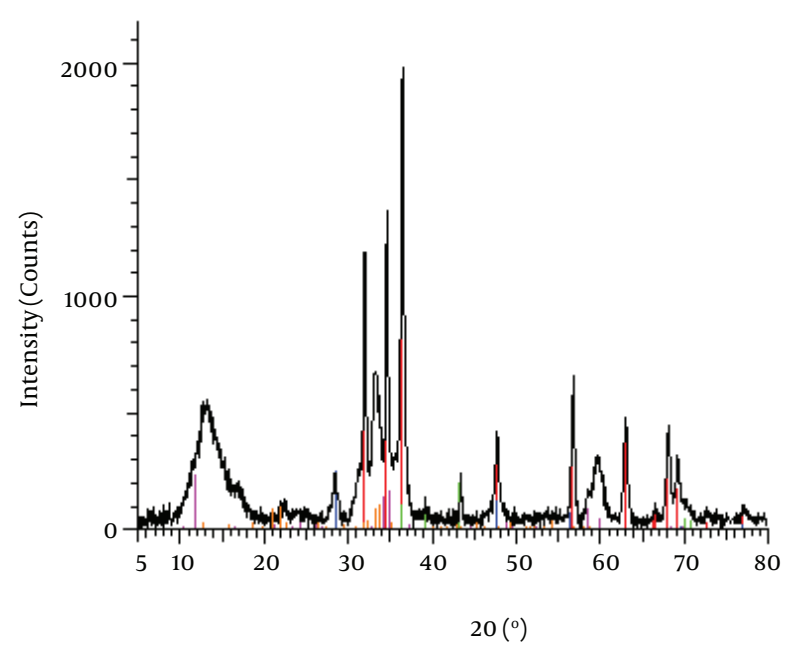

\begin{tabular}{|c|c|c|c|c|}
\hline $\begin{array}{l}\text { Line } \\
\text { Color }\end{array}$ & Compound Name & Formula & PDF Number & $\begin{array}{c}\text { Concentration } \\
\text { (W/W\%) }\end{array}$ \\
\hline 口 & Zincite, syn & $\mathrm{ZnO}$ & $36-1451$ & 78.1 \\
\hline$\square$ & Sphalente, syn & $\mathrm{ZnS}$ & 05-0566 & 3 \\
\hline$\square$ & Zinc, syn & $\mathrm{Zn}$ & 04-0831 & 2.5 \\
\hline$\square$ & $\begin{array}{c}\text { Zinc Sulfate } \\
\text { Hydroxide } \\
\text { Hydrate }\end{array}$ & $6 \mathrm{Zn}(\mathrm{OH})_{2} \mathrm{ZnSO}_{4}^{\prime} 4 \mathrm{H}_{2} \mathrm{O}$ & O $11-0280$ & 11.2 \\
\hline$\square$ & $\begin{array}{l}\text { Zinc Sulfite } \\
\text { Hydrate }\end{array}$ & beta- $\mathrm{ZnSO}_{3}-2.5 \mathrm{H}_{2} \mathrm{O}$ & $34-0320$ & 5.2 \\
\hline
\end{tabular}

Figure 1. XRD Data of Zn Metal Surface with Bacterial Biomass of P.Stutzeri Incubated for 2 weeks at $27^{\circ} \mathrm{C}$

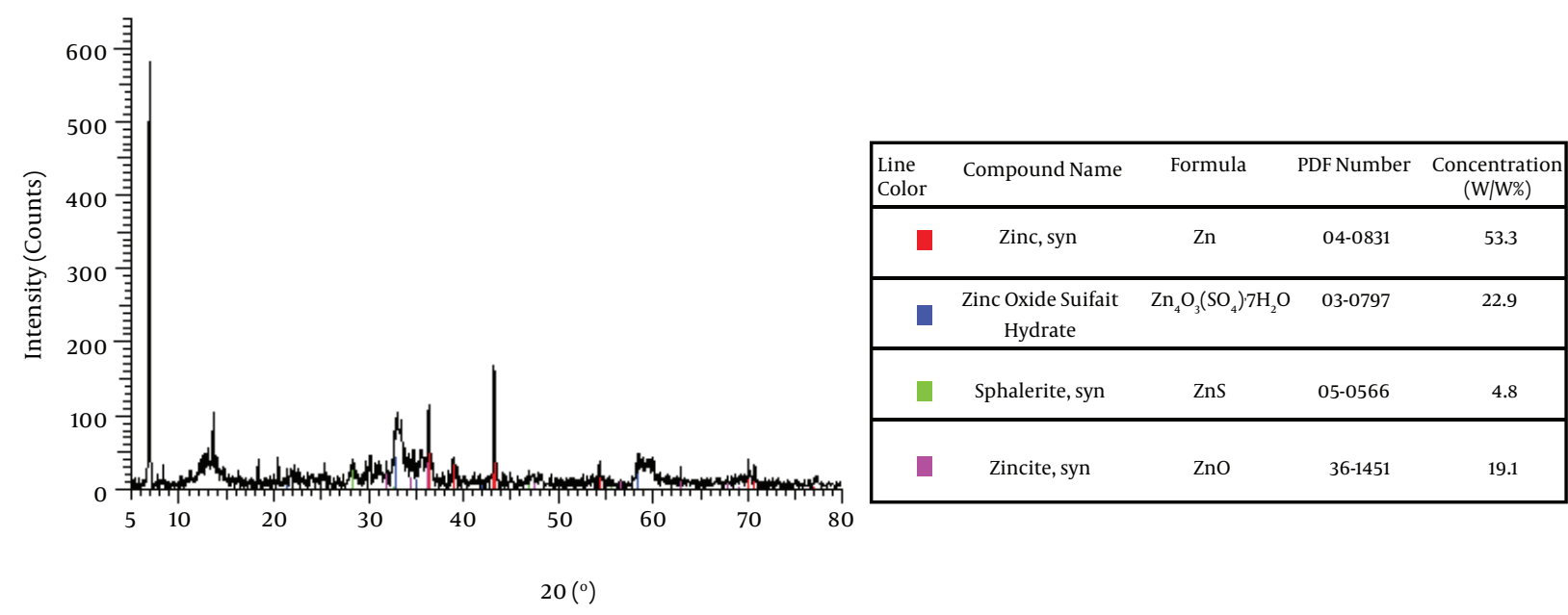

Figure 2. Effect of $\mathrm{Na}_{2} \mathrm{~S} 0.04$ MonNanoZn Production by P. stutzeri in Nutrient Agar Incubated for 2 Week at $27^{\circ} \mathrm{C}$ in Aerobic Conditions

\section{Results}

The resistant $P$. stutzeri isolated from enriched soil containing MTBE was a Gram negative, fast growing bacterium with yellow pigment. Inoculation of this strain in nutrient agar with sterilized zinc metal produced a biofilm colored yellow and white on zinc metal. The obtained data by XRD is shown in Figure 1. As demonstrated, this bacterium produced nano size particles of $\mathrm{ZnO}$ (sized $16.35 \mathrm{~nm}$ ), ZnS (sized $12 \mathrm{~nm}$ ), and $\mathrm{Zn}$ (sized $44 \mathrm{~nm}$ ). Most of the nano $\mathrm{Zn}$ produced was nano $\mathrm{ZnO}$. The percentage of nano particles was assayed by XRD. Results showed that the produced nano $\mathrm{ZnO}$, nano $\mathrm{ZnS}$, and nano $\mathrm{Zn}$ were $78.7 \%$, 3\% and 2.5\% respectively. Nonanoparticle was detected by XRD analyses in the supernatant showing that nanoparticles are on cell surfaces of bacteria.

The effect of $\mathrm{Na}_{2} \mathrm{~S}$ on $\mathrm{ZnS}$ production is shown in Figure 2. As demonstrated, the percentage of zinc oxide sulfate produced was $22.9 \%$ while this was lower forZnS (4.8\%). Also UV adsorption of ZnS at $340 \mathrm{~nm}$ indicates the production of $\mathrm{ZnS}$, which is shown by Figure 3. On the other hand, amount of produced ZnS was higher in aerobic conditions at $\mathrm{PH}=12$. The highest yield was for nano $\mathrm{Zn}$ in aerobic condition i.e. $85.8 \%$ as shown by 
Figure 4. Mixed nanoparticles produced by P. stutzeri showed magnetite properties under aerobic and anaerobic conditions. The best condition for producing nano zinc was $\mathrm{pH}=7$, in the light at $37^{\circ} \mathrm{C}$.

The PCR reaction of $\mathrm{CzcC}$ gene was done for P. stutzeri. As indicated by Figure 5, CzcC gene has a size of $399 \mathrm{~Kb}$. Our results suggest that the isolated strain contains a resistance gene to Zinc with the ability of producing zinc nanoparticles. The antibacterial activity of nano ZnO was detected against E. coli and S. aureus, as shown in Table 1.

Table 1. The Antibacterial Activity of NanoZnOAgainst Some Gram Positive and Negative Bacteria

\begin{tabular}{ll}
\hline Bacteria & Zone of Inhibition $(\mathbf{m m})$ \\
\hline Escherichia coli & 10 \\
\hline Staphylococcus aureus & 4 \\
\hline Pseudomonas stuzeri & 22 \\
\hline Brevundimonas diminuta & -- \\
\hline
\end{tabular}

The highest activity was seen against $P$. stutzeri with zone of inhibition of $22 \mathrm{~mm}$. No antibacterial activity was detected against $B$. diminuta.

Overall, in this study, pure culture of P. stutzeri was able to produce nano $\mathrm{Zn}$, nano $\mathrm{ZnO}$, nano $\mathrm{ZnS}$ and etc.,as in- dicated by Figure 1 and Figure 2. The presence of specific genes such as CzcC in P. stutzeri was confirmed, as a gene involved in resistant to zinc. Also, magnetite properties of the produced nanoparticles, the effect of their toxicity on other bacteria and the best condition for producing zinc were assayed.

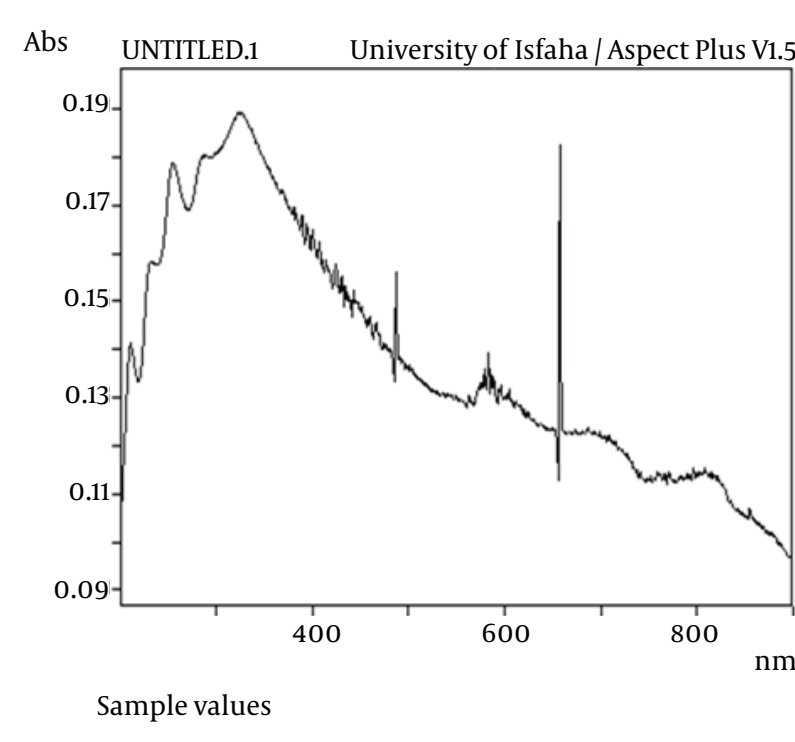

Figure 3. UV Adsorption of Nano Zn Produced by P. stutzeri

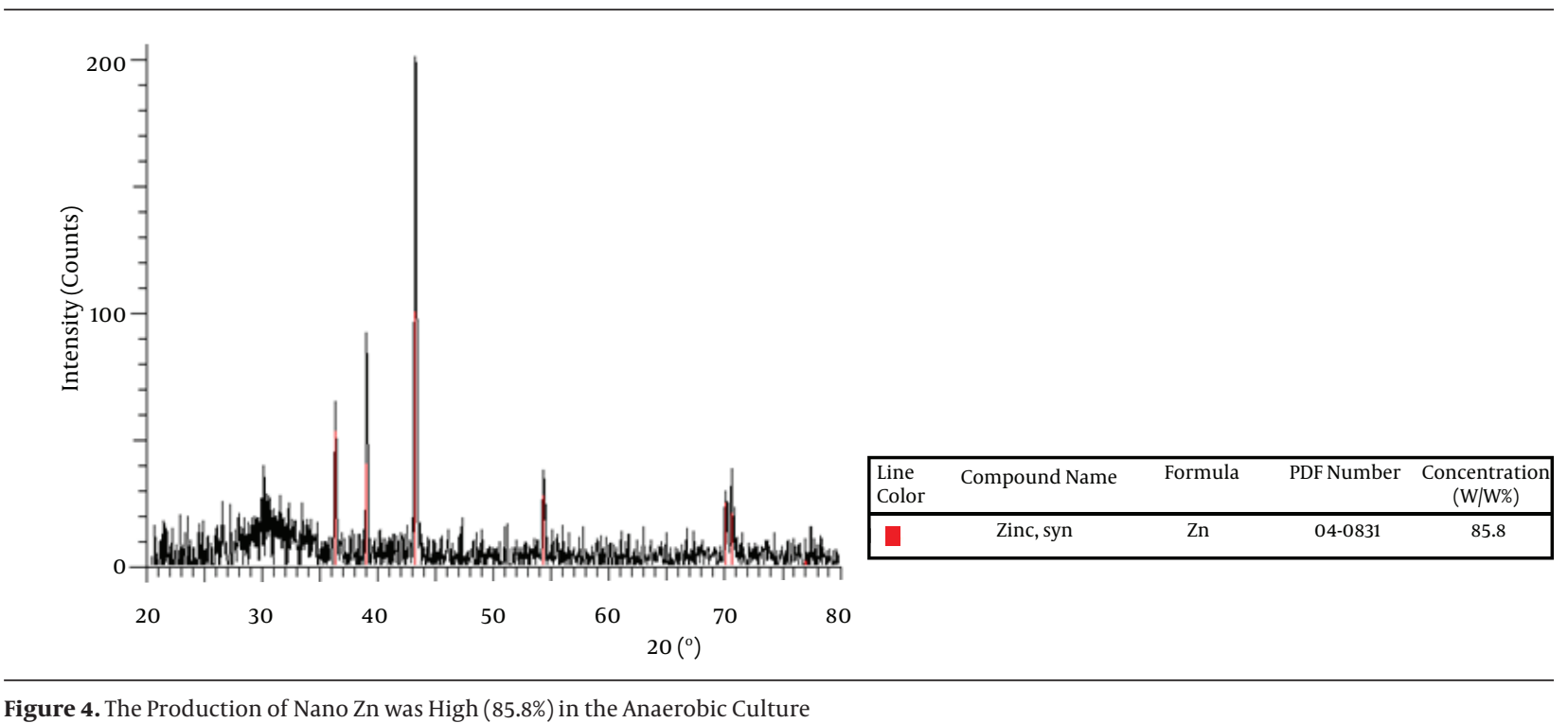




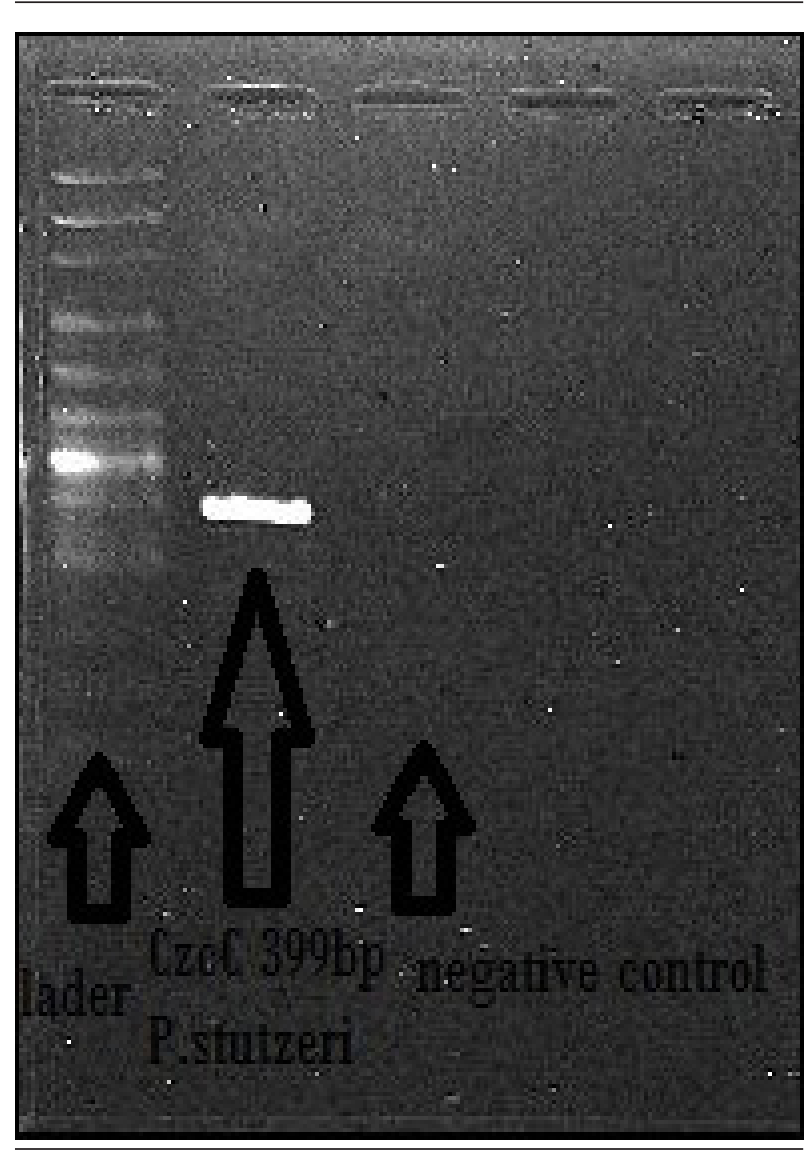

Figure 5. CzcC Gene With 399Kb Size Observed in P. stutzeri

\section{Discussion}

Zinc, zinc oxide and zinc sulfide nanoparticles are used for various biomedical, petrochemical and antibacterial applications due to their reactive characteristics (11-17). Synthesis of nano ZnO, nano ZnS and nano Zn is done by physical and chemical methods, which require high temperatures or pressure. Also, their production causes lots of problems as well as contamination (2-5). Thus, their synthesis needs to be substituted by biological methods. The advantages of biological assays are that they are nontoxic, clean, cost effective and compatible with Eco (Green Chemistry).

In this study, a resistant bacterium i.e. P. stutzeri was a good candidate for producing zinc nanoparticles. The reasons that $P$. stutzeri was used in this study, was the presence of metal resistance genes in this bacterium. Different types of zinc nanoparticles were produced by $P$. stutzeri. By optimizing the environmental conditions, the highest yield was gained for zinc oxide (78.1\%). There are a few reports regarding the anti-bacterial activity of zinc oxide nanoparticles on Gram positive and negative bacteria $(17,23)$. It needs to be mentioned that previous reports on producing ZnOnanoparticles were prepared by wet chemical methods which were directly applied on to the
$100 \%$ cotton woven fabric (17). Their results showed that the finished fabric confirmed considerable anti-bacterial activity against $S$. aureus in both qualitative and quantitative tests (17).

Iron is particularly important in magnetotactic bacteria because these microorganisms incorporate large amounts of iron in the form of nano magnetite iron mineral crystals within their cells (24). The magnetic property of ferrite zinc formed by a microbial process was shown previously by chemical methods. A metal reducing bacterium, thermoanaerobacter, has been shown to produce nanoparticulates of ferrite zinc (25). In the present work, the produced zinc nanoparticles had magnetite properties in the vicinity of the bacterial cells that might be a result of cytochrome or other Fe proteins, that conjugate with nano zinc and magnetite produced particles.

The most important reason for choosing P.stuteri for producing zinc nanoparticles was the resistance gene in this bacterium. The specific primers for zinc resistance CzcC gene was designed and P.stuteri was amplified by PCR and the results showed that the gene was present in the isolate, so it is probably that the zinc resistant microorganism is able to produce nano zinc particles too. This gene was also observed on other bacteria $(26,27)$.

To the best of our knowledge, production of zinc nanoparticles including zinc oxide nanoparticles, nano zinc sulfide, and nano zinc has not been reported for any microorganisms while, recently, production of zinc sulfate nanoparticles, has been reported for a species of Streptomyces (21). Although in previous studies it was shown that $P$. stutzeri is able to produce silver nanoparticles in a silver salt solution (20), but in this study, for the first time $\mathrm{ZnO}$, ZnS, and $\mathrm{Zn}$ nanoparticles were detected on a biofilm of zinc metal.

\section{Acknowledgements}

The authors would like to thank Elaheh Heidari for isolation of P. stutzeri strain CS-Z on MTBE enriched soil.

\section{Authors' Contribution}

None declared.

\section{Financial Disclosure}

There is no financial disclosure.

\section{Funding/Support}

This work has been supported by the Department of Biology, University of Isfahan.

\section{References}

1. Emtiazi G, Harirchi S. Molecular Nanobiotechnology (Prokaryotes). 1st edIsfahan, Iran: Mani Publication;2009.

2. Aneesh PM, Vanaja KA, Jayaraj MK editors. . Synthesis of ZnO nanoparticles by hydrothermal method. Nano Sci Engin.; 2007: International Society for Optics and Photonics. p. 66390J66390J-9. 
3. She YY, Yang J, Qiu KQ. Synthesis of ZnS nanoparticles by solidliquid chemical reaction with $\mathrm{ZnO}$ and $\mathrm{Na} 2 \mathrm{~S}$ under ultrasonic. Transactions of Nonferrous Metals Society of China. 2010;20:s211s215.

4. Ghaffarian HR, Saiedi M, Sayyadnejad MA, Rashidi AM. Synthesis of ZnO Nanoparticles by Spray Pyrolysis Method. IJCCE. 2011;30(1):1-6.

5. Guan YF, Pedraza AJ. Synthesis and alignment of $\mathrm{Zn}$ and $\mathrm{ZnO}$ nanoparticles by laser-assisted chemical vapor deposition. Nanotechnology. 2008;19(4):45609.

6. Hosseinkhani B, Sobjerg LS, Rotaru AE, Emtiazi G, Skrydstrup T, Meyer RL. Microbially supported synthesis of catalytically active bimetallic Pd-Au nanoparticles. Biotechnol Bioeng. 2012;109(1):4552.

7. Krumov N, Perner-Nochta I, Oder S, Gotcheva V, Angelov A, Posten C. Production of Inorganic Nanoparticles by Microorganisms. Chem Engin Technol. 2009;32(7):1026-1035.

8. Natrajan K, Selvaraj S, Ramamurthy VR. Microbial production of silver nanoparticles. Digest J Nanomaterials Biostruct. 2010;5(1):135-140.

9. Pugazhenthiran Nalenthiran, Anandan Sambandam, Kathiravan Govindarajan, Prakash Nyayiru Kannaian Udaya, Crawford Simon, Ashokkumar Muthupandian. Microbial synthesis of silver nanoparticles by Bacillus sp. J Nanoparticle Res. 2009;11(7):18111815.

10. Yaaghoobi M, Emtiazi G, Roghanian R. A novel approach for aerobic construction of iron oxide nanoparticles by acinetobacter radioresistens and their effects on red blood cells. Curr Nanosci. 2012;8(2):286-291.

11. Ansari SA, Husain Q, Qayyum S, Azam A. Designing and surface modification of zinc oxide nanoparticles for biomedical applications. Food Chem Toxicol. 2011;49(9):2107-15.

12. Kim DCh, Jang A, Kang DJ. Fabrication of layer-by-layer assembled bio-architecture on gold nanorods. Korean Phys Society. 2008;536(2):886-891.

13. Nohynek GJ, Dufour EK, Roberts MS. Nanotechnology, cosmetics and the skin: is there a health risk? Skin Pharmacol Physiol. 2008;21(3):136-49.

14. Xing Y, Rao J. Quantum dot bioconjugates for in vitro diagnostics \& in vivo imaging. Cancer Biomark. 2008;4(6):307-19.

15. Aslam M, Chaudhary VA, Mulla IS, Sainkar SR, Mandale AB, Belhekar AA, et al. A highly selective ammonia gas sensor using surface-ruthenated zinc oxide. Sensors and Actuators A: Physical.
1999;75(2):162-167.

16. Sayyadnejad MA, Ghaffarian HR, Saeidi M. Removal of hydrogen sulfide by zinc oxide nanoparticles in drilling fluid. Int J Environ Sci Technol. 2008;5(4):565-569.

17. Rajendra R, Balakumar C, Ahammed Hasabo A Mohammed, Jayakumar S, Vaideki K, Rajesh E. Use of zinc oxide nano particles for production of antimicrobial textiles. Int J Engin Sci Technol. 2010;2(1):202-208.

18. Anyanwu CU, Nwachukwu ON. Heavy metal resistance in bacteria isolated from contaminated and uncontaminated soils. . Res Chem Environ. 2011;1(1):173-8.

19. Iiyas S, Anwar MA, Niazi SB, Ghauri MA, Ahmad HB, Khan KM. Bioleaching of Pb-Zn ore by moderate thermophilic chemolithotrophic bacteria. . J Chem Society Pakistan. 2008;30(1):61-8.

20. Klaus T, Joerger R, Olsson E, Granqvist CG. Silver-based crystalline nanoparticles, microbially fabricated. Proceedings National Academy Sci.1999;96(24):13611-13614

21. Waghmare SS, Deshmukh AM, Kulkarni SW, Oswaldo LA. Biosynthesis and characterization of manganese and zinc nanoparticles. Res Technol. 2011;1:64-9.

22. Bauer AW, Kirby WM, Sherris JC, Turck M. Antibiotic susceptibility testing by a standardized single disk method. Am J Clin Pathol. 1966;45(4):493-6.

23. Heinlaan M, Ivask A, Blinova I, Dubourguier HC, Kahru A. Toxicity of nanosized and bulk $\mathrm{ZnO}, \mathrm{CuO}$ and $\mathrm{TiO} 2$ to bacteria Vibrio fischeri and crustaceans Daphnia magna and Thamnocephalus platyurus. Chemosphere. 2008;71(7):1308-16.

24. Bazylinski DA, Frankel RB, Heywood BR, Mann S, King JW, Donaghay PL, et al. Controlled Biomineralization of Magnetite (Fe(inf3)O(inf4)) and Greigite (Fe(inf3)S(inf4)) in a Magnetotactic Bacterium. Appl Environ Microbiol.1995;61(9):3232-9.

25. Yeary LW, Moon JW, Rawn CJ, Love LJ, Rondinone AJ, Thompson $\mathrm{J}$ R, et al. Magnetic properties of bio-synthesized zinc ferrite nanoparticles. J Magnetism Magnetic Materials. 2011;323(23):30433048.

26. Beard SJ, Hashim R, Membrillo-Hernández J, Hughes MN, Poole RK. Zinc(II) tolerance in Escherichia coli K-12: evidence that the zntA gene (o732) encodes a cation transport ATPase. Mol Microbiol.1997;25(5):883-891.

27. Yang Y, Zhu H, Colvin VL, Alvarez PJ. Cellular and transcriptional response of Pseudomonas stutzeri to quantum dots under aerobic and denitrifying conditions. Environ Sci Technol. 2011;45(11):4988-94. 